This article was downloaded by: [Kennedy, Rosanne]

On: 6 April 2009

Access details: Access Details: [subscription number 907828527]

Publisher Routledge

Informa Ltd Registered in England and Wales Registered Number: 1072954 Registered office: Mortimer House, 37-41 Mortimer Street, London W1T 3JH, UK

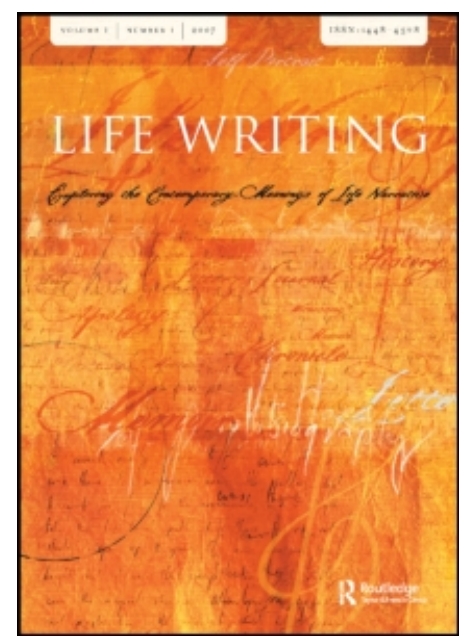

\title{
Life Writing
}

Publication details, including instructions for authors and subscription information:

http://www.informaworld.com/smpp/title content=t762290978

\section{Vulnerable Children, Disposable Mothers: Holocaust and Stolen Generations Memoirs of Childhood \\ Rosanne Kennedy}

Online Publication Date: 01 October 2008

To cite this Article Kennedy, Rosanne(2008)'Vulnerable Children, Disposable Mothers: Holocaust and Stolen Generations Memoirs of Childhood',Life Writing,5:2,161 - 184

To link to this Article: DOI: $10.1080 / 14484520802386535$

URL: http://dx.doi.org/10.1080/14484520802386535

\section{PLEASE SCROLL DOWN FOR ARTICLE}

Full terms and conditions of use: http://www.informaworld.com/terms-and-conditions-of-access.pdf

This article may be used for research, teaching and private study purposes. Any substantial or systematic reproduction, re-distribution, re-selling, loan or sub-licensing, systematic supply or distribution in any form to anyone is expressly forbidden.

The publisher does not give any warranty express or implied or make any representation that the contents will be complete or accurate or up to date. The accuracy of any instructions, formulae and drug doses should be independently verified with primary sources. The publisher shall not be liable for any loss, actions, claims, proceedings, demand or costs or damages whatsoever or howsoever caused arising directly or indirectly in connection with or arising out of the use of this material. 


\section{Vulnerable Children, Disposable Mothers: Holocaust and Stolen Generations Memoirs of Childhood}

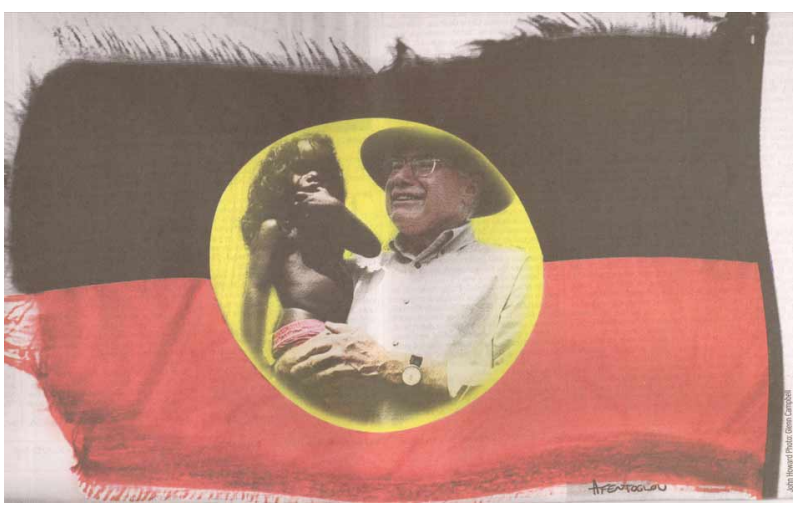

\section{Rosanne Kennedy}

In recent years, historians have pioneered comparative research on the Holocaust and colonisation in Australia. This article seeks to demonstrate that a comparative reading of Stolen Generations and Holocaust memoirs can generate unique and challenging insights into the affective, material and psychological legacies of the assimilation of children across racial and ethnic divides. By placing Sarah Kofman's memoir, Rue Ordener, Rue Labat, into dialogue with versions of the Rabbit Proof Fence narrative, the article considers how the gendered trope of suffering mothers and vulnerable children has been used to mediate the trauma of childhood assimilation, and reveals aspects of this legacy that remain unspeakable in Australia.

Keywords trauma memoir; maternal trope; comparative trauma studies; cultural memory 


\section{Reading Trauma through an Antipodean Lens}

Writing about Holocaust testimony, French historian Annette Wieviorka observes that the 1997 trial of Maurice Papon, the last significant war crimes trial in France, marked the delegation of witnessing to a new generation: children who were hidden during the war (145). Esther Fogiel 'mesmerized the audience' with her testimony of the horrific abuse she suffered, including rape, forced labour and psychological abuse, at the hands of a violent couple in whose care her parents had left her, as an eight-year old, before they were deported (146). While insisting that Fogiel is 'an extreme case', Wieviorka observes that 'her sufferings, even her suicide attempt, are echoed' in the experiences of many hidden children who are now expressing themselves (148). Memoirs by hidden children, whom Susan Seulieman describes as the '1.5 generation', extend the cultural memory of the Holocaust. They bring into discourse the legacy of this traumatic past on children whose lives were massively disrupted by persecution and separation from their parents, and who lived in fear of deportation, death and the loss of family (Pine 375). Today these memoirs of Holocaust childhoods circulate alongside narratives of child separation from very different historical and cultural contexts. Their transnational circulation invites a comparative reading that explores how tropes of maternal and child relations emerge in these narratives of traumatic memory.

Sarah Kofman's memoir, Rue Ordener, Rue Labat, is an unusual example of 'the hidden child' genre, in part because she was hidden with her mother. A highly regarded French feminist philosopher, Kofman begins her elegantly sparse memoir with her father's arrest in Paris, during the infamous round-up of Jews on July $16,1942 .{ }^{1}$ A rabbi of a small synagogue, he was sent to Drancy and later deported to Auschwitz. After the war, his family was told that he had been brutally beaten and buried alive for praying on the Sabbath rather than working. While the ghost of her father haunts the memoir, the emotional core centres on the eighteen months she and her mother spent in hiding in a small apartment with Meme, a Christian woman 'who loves children' (31). Kofman represents Meme as a captivating but predatory woman who uses the intimate domestic circumstances to lure Sarah away from her mother and Judaism. The strong attachment Sarah forms with Meme results in her estrangement from her mother, which remains an unresolved trauma throughout her life. Rather than echo Fogiel's testimony of childhood innocence and adult tyranny, Kofman's memoir introduces a less familiar and troubling narrative of seduction, betrayal and petty cruelty. Although she was only nine years old, and had already suffered irreparable losses, she positions herself as complicit in the betrayal of her mother. Less than a year after she published this memoir, Kofman took her own life. ${ }^{2}$ Her suicide is a potent reminder that bearing witness to trauma does not necessarily aid survival, as the late psychoanalyst Dori Laub had hoped. ${ }^{3}$

Of course, the significance of Rue Ordener, Rue Labat, which was published in France in 1994, the year of Paul Trouvier's trial for war crimes, differs depending upon when, where and by whom it is read. In France, Kofman's autobiographical 
writing coincided with the belated awakening of Jewish memory in the 1980s and 1990s, which historian Henry Russo has dubbed the 'Obsessions' period. ${ }^{4}$ During this period the post-war narrative of French resistance was challenged, the role of French police units in arresting and deporting French Jews was exposed, and numerous collaborationist scandals emerged. It was revealed, for instance, that President Mitterand, honoured as a hero in the resistance, was personal friends with Rene Bousquet, chief of Vichy police and organiser of the Vel'd Hiv roundups, whom French Jews were anxious to try for war crimes (Golasan 89). Kofman's memoir of complicity and betrayal echoed the nation's painful confrontation with its hidden past, and exposed the partiality of the heroic narrative offered at Meme's funeral of a woman who 'saved a little Jewish girl during the war' (85).

In Australia, the late 1990s was marked by a long overdue reckoning with the post-colonial legacy of what has become known as the 'Stolen Generations'. In 1996, the Human Rights and Equal Opportunity Commission conducted a landmark National Inquiry into the policies, practices and effects of removing children of mixed Aboriginal and Caucasian descent from their families and communities. The Inquiry travelled around the country collecting testimonies from individuals who had been removed, giving them an opportunity - many for the first time - to tell their stories. Like Esther Fogiel's Holocaust testimony, many Stolen Generations testimonies tell shocking stories of the physical, sexual and emotional abuse of children, and of adulthoods scarred by drug dependency, violence and suicide attempts. Themes of maternal loss and childhood loneliness recur in these testimonies. For example, individuals repeatedly describe being callously removed from their families, and later discovering in their files letters from their grief-stricken mothers, whom they had been told were dead or had abandoned them. In 1997, the Inquiry published its powerful report, Bringing Them Home. The cover features a photograph of an Aboriginal woman and child playing a game by a river, framed in silhouette against the sunset. This idealised image of the mother-child relation, associated with nurture, pleasure, intimacy and cultural continuity, intensifies the shock of the violent breaches documented within the text, and signals the value of a maternal trope as a symbolic vehicle for mediating the cultural memory of the Stolen Generations.

Drawing on a discourse of ethical witnessing, Bringing Them Home addressed Australians in moral and affective terms, asking them to listen to the testimonies of stolen children with 'open hearts and minds' (Wilson 3). Through this address, the report implicitly positioned the Stolen Generations as victims, and nonIndigenous Australians as belated witnesses to the history of colonisation and child removal. While the report elicited an empathic response from nonIndigenous Australians and generated support for reconciliation, it is important to acknowledge the political and moral limits of empathy. Empathy, when it leads to an unexamined identification with the victim, may distract Australians from recognising our own positions as participants in and beneficiaries of colonisation. ${ }^{5}$ As Dominick LaCapra reminds us, in cases of historical injustice, there are often 'divided legacies' — some groups and individuals have been victims while others 
have benefited, which raises the problem of how to acknowledge and work though 'historical losses in ways that affect different groups differently...' (44-45). Rather than acknowledge these divided legacies, the binary of 'victim' and 'belated witness' obscures the range and complexity of subject positions that non-Indigenous and Indigenous Australians occupy in relation to this past. ${ }^{6}$ This framing also makes it difficult to acknowledge responses such as denial, ambivalence, and neglect (Kennedy 2004)

In recent years, a number of scholars have been engaged in comparative research on the Holocaust and colonisation in Australia, and have begun to explore these issues. ${ }^{7}$ In an insightful essay, Neil Levi contends that a comparative approach can fruitfully throw into relief silences and limits in the discourse of the History Wars in Australia. He argues that a comparative approach to the Holocaust and the Stolen Generations is considered illegitimate by white Australians because we cannot see ourselves as perpetrators of genocide (137-139). Nor, I would add, do we see ourselves as beneficiaries of colonisation. While historians have pioneered comparative approaches to these histories, I suggest that a comparative reading of Stolen Generations and Holocaust memoirs of childhood can generate unique and challenging insights into the complex affective, material and psychological legacies of the assimilation of children across racial and ethnic divides. By bringing Kofman's atypical Holocaust memoir of the seductions and estrangements of assimilation into Antipodean life narrative, I aim to illuminate aspects of Indigenous child removal that have been obscured by the dominant cultural memory of the Stolen Generations. ${ }^{8}$

Kofman's memoir was translated into English in 1996, the year of the National Inquiry. ${ }^{9}$ In a discourse that resonates uncannily in Australia, Kofman describes her mother's struggle after the liberation:

... to reclaim me from the woman who wanted to 'steal' me on the pretext that my own mother had more than enough to handle with five other children and wasn't looking after my best interests - which were, according to Meme, not to be raised by my own mother but rather to be brought up by Meme herself (58).

The scenario of Aboriginal children being 'stolen' from their mothers to be raised by white women, alleged to have been in the 'best interests of the child', has figured in Australian cultural narratives of assimilation long before the National Inquiry. For instance, these themes are explored in Charles Chauvel's classic 1955 film Jedda, in which a white woman, whose own infant has died, 'rescues' or 'steals' an Aboriginal baby after its mother dies, and raises her as a white child. ${ }^{10}$ In Jedda white Australians are represented as participants in rather than as belated witnesses to practices of colonisation and child removal. Mrs McCann, Jedda's adoptive mother, is both a perpetrator and beneficiary of the child's removal, which positions her as complicit in the process of assimilation and cultural loss. Through the blindness that results from her own maternal desire, masked as a 'benevolent intention' to 'improve' Jedda's lot in life, she is implicated in Jedda's estrangement from her culture and her tragic death. 
Reflection on the position of the beneficiary has been obscured in Australia by discourses of child protection, and by the sentimental tropes of maternity and childhood that are the preferred readings of narratives of Indigenous child removal and assimilation. ${ }^{11}$ Read in this context, Kofman's narrative of theft disavowed as rescue invites reflection on the positions and unacknowledged desires of the beneficiary and the victim.

In this article I read Kofman's memoir in relation to the text and film versions of an important Australian cultural memory of the Stolen Generations. Doris Pilkington's bio-memoir, Follow the Rabbit-Proof Fence, published in 1996, tells the story of the removal of her mother Molly, her aunt Daisy and their cousin Gracie from the remote community of Jigalong in the Northern Territory in 1931, when they were aged 14, 11 and 8 . Their removal was arranged by A. O. Neville, the Chief Protector of Aborigines in Western Australia. Guided by notions of white superiority and a pseudo-scientific discourse of eugenics, he developed policies to assimilate and 'absorb' Aborigines of mixed descent into the white population and thereby eradicate Aboriginal culture. While Kofman and Pilkington's influences, traditions and styles differ markedly, there are compelling historical reasons for placing their memoirs in dialogue on the subject of maternal tropes in narratives of child separation and assimilation. Pilkington was born in 1936 at Balfour Downs station in Western Australia, two years after Sarah Kofman's birth in Paris. Both were members of groups targeted by the transnational eugenics discourse and policies of the 1930s and 1940s. As a young child, Doris was taken with her mother Molly and her infant sister Annabelle to Moore River Native Settlement, where she remained for the duration of her childhood, after her mother absconded with her sister. ${ }^{12}$ Half a world away, Kofman was in hiding from the Gestapo. Both women published memoirs of childhoods disrupted by trauma in the mid-1990s, more than fifty years after the events, exemplifying the insight that 'the belated nature of trauma itself is a transcultural phenomenon’ (Brodzki 133).

\section{The Maternal Trope}

In one of the few articles to consider the gendering of trauma discourse, psychoanalytic literary critic Claire Kahane reflects upon the frequency with which scenes of anguished separation of mother and child recur in Holocaust literature and film. She argues that '.. the profound intimacy between mother and child and its callous violation is a powerful and moving signifier, effectively capturing the perversion of human bonds that was a primary consequence of the Holocaust' (164). As well as signifying trauma and moments of social breakdown, she suggests that writers use the figure of 'the female in pain' because it compels the reader's identification (165). As she reminds us, however, even when scenes of mother and child separation have a historical referent such as the Holocaust or the Stolen Generations, their translation into text '.... asks us not merely to experience their painful affect but to question their function within the context 
of cultural representation and the social effects of their transmission' (165). While Kahane focuses on Holocaust literature, the maternal trope is transcultural in its reach, elastic in its applicability, and discursively mobile. It is regularly used by journalists and filmmakers to mediate unfamiliar or distant events for global audiences, who may lack historical and local knowledge, but can identify with the figure of the suffering woman and child.

In the Australian context, the maternal trope has been ubiquitous in shaping the cultural memory of the Stolen Generations. In the wake of Bringing Them Home, which used a mother/child image to frame its findings, the maternal trope has figured in memorials, songs, artwork, films such as Rabbit-Proof Fence, and media discourse. Yet, despite its recurrence, scarce attention has been paid to the discursive effects of this gendered trope in shaping the cultural memory of the Stolen Generations. As Marianne Hirsch argues, however, '[a] feminist analysis ... can enhance our understanding of the structure and politics of memory and transmission, illuminating not just what stories are told, or what images are seen, but how those stories are told and how those images are constructed (Hirsch, Phototextualities 23). A feminist analysis allows the critic to consider troubled and troubling narratives of maternal and child conflict, which explore resentment and rejection, as well as familiar sentimental versions of maternal relations. Moreover, the continuing use of the figure of the vulnerable child in the discourse of Indigenous child protection in Australia today, which I discuss in the final section, makes a gendered analysis crucially important.

While Kahane's article raises important issues about the gendering of cultural memories of trauma, there are certain assumptions that need to be addressed to make it relevant to Stolen Generations discourse. Like many trauma critics, Kahane privileges literary discourse as the cultural form most capable of conveying the affect of trauma. She contends that 'through its semiotic strategies of encoding and conveying affect' literary discourse 'can make real and present the inaccessible historical past and the experience of the other' and 'can transmit the texture of traumatic memory' (163-64). In Indigenous Australian culture, memory is typically passed on through vernacular languages such as oral storytelling rather than through literary discourse (Bennett and Kennedy 11). Many narratives of Indigenous child removal have been transcribed from oral interviews and testimonies produced in a collaboration between Indigenous witnesses and Indigenous and non-Indigenous historians, lawyers, and ethnographers. Figurative devices are inevitably used to shape these narratives, but they are usually not 'worked through' to the degree that much Holocaust testimony is (Felman and Laub 5). As Bella Brodzki points out, even within literary discourse, various strategies are used to convey trauma. In some trauma texts the author '... renders an experience of terror, horror, or shame explicitly, directly, almost didactically, perhaps using the word trauma itself ... .' (128). In other texts, traumatic memory may be registered linguistically through the structure of the text, and through devices such as figures, flashbacks and repetitions (130). The particular forms that are used to transmit memories of 
trauma are diverse and shaped by a range of factors, including cultural and linguistic traditions, and generic conventions. In recognition of this cultural diversity, it is important to challenge the widespread claim that literary discourse is uniquely suited to transmit the affect and experience of trauma from victim to secondary witness. It is also worth questioning the assumption that it is possible or desirable to transmit the experience of trauma and loss to others, especially where there are vast differences of culture and experience involved. Perhaps some traumatic experiences can only be acknowledged and survived.

\section{Rabbit-Proof Fence}

Philip Noyce's 2002 film Rabbit-Proof Fence, an adaptation of Pilkington's narrative, is one of the few Stolen Generations narratives to circulate internationally. A rare escape story, the film follows Molly, Gracie and Daisy as they escape from Moore River Native Settlement, and walk an arduous 1600 kilometres through bush and desert, guided by the rabbit-proof fence, back to home and mother. Together Pilkington's narrative and Noyce's film offer the opportunity to examine how the cultural memory of the Stolen Generations has been mediated, not only by literary and cinematic conventions, but by transnational discourses of trauma and the Holocaust. Not only is the film mediated by the Bringing Them Home report (Collins and Davis 133). It aimed to be the Schindler's List of the Stolen Generations: a representative story standing for a multitude of other stories. Hughes D'aeth has convincingly argued that Rabbit-Proof Fence is 'visually' and 'conceptually linked' to Schindler's List, although he does not consider the gendered dimensions of the transnational Holocaust iconography Noyce cites. ${ }^{13}$ One of the most striking features of Noyce's adaptation is his use of the maternal trope to construct a powerful cultural memory of the Stolen Generations, and to mediate this story for international audiences. To draw out the contrast between text and film versions, I first consider Pilkington's text.

As someone who was herself forcibly assimilated into white Australian culture as a child, Pilkington occupies a hybrid position, as an insider and outsider to an Aboriginal culture that was irreversibly transformed by colonisation. Reconstructing the story of her mother and aunt's journey from their oral testimonies, archival sources, and her own childhood memories of the landscape surrounding Moore River, she articulates the challenges of translating Aboriginal forms of knowledge for Western readers, while still conveying their cultural specificity and difference (Pilkington 1996, xii). Although she places the story of the girls' removal in the broader context of dispossession and colonisation, she writes in a voice that strives not to accuse. The story opens with a collective mythic Indigenous memory of the arrival of Europeans in the 1800s, and the first settlement in what is now Western Australia. Over time, as a result of dispossession and scarcity of traditional food sources, some Aboriginal clans 
move into Jigalong, a government depot that offered food and security. Molly and her cousins, the first children of mixed-descent in the area, were taunted by the 'full-blood' children, which was noticed by the depot manager, and communicated to Neville as a reason for removing them. The narrator reports that '[p]olicies were introduced by the government ... to provide for the welfare and education needs of these children' (40). This passive construction removes responsibility for assimilation policies from any individual, and apparently accepts that they were formulated with benevolent intentions. It is worth recalling, however, that Pilkington's narrative was published before Bringing Them Home, when the history and effects of these policies were not widely known or acknowledged by non-Indigenous Australians.

Without apportioning blame, the narrative represents child removal as a devastating and cataclysmic event that affected the whole Aboriginal clan. In the scene in which Molly, Daisy and Gracie are being taken, Officer Riggs explains to the clan that the girls will be sent to school to be educated:

The old man nodded to show that he understood what Riggs was saying. The rest of their family just hung their heads ... Molly and Gracie sat silently on the horse, tears streaming down their cheeks .... A high pitched wail broke out. The cries of agonised mothers and the women, and the deep sobs of grandfathers, uncles and cousins filled the air ... .those remaining in the camp found strong sharp objects and gashed themselves and inflicted wounds to their heads and bodies as an expression of their sorrow (44-45).

Grief and despair are conveyed through universal codes such as sobbing and wailing, and through self-inflected wounds to the head, '... a customary [Aboriginal] action of the distressed and the anguished' (131). Through such signifiers, the narrative directly represents the grief and social suffering caused by removal. In this scene, the response to removal is neither individualised nor gendered; the whole group participates, and the men as well as women express distress. When Gracie's mother accuses the child's white father of doing nothing to prevent her removal, he reminds her that Gracie is his daughter too, and that he is powerless to prevent her removal.

Pilkington situates child removal in the context of white settlement and the dispossession of Indigenous people from their lands. Noyce, however, focuses on the maternal melodrama. The film begins with text that explains the policy of child removal in Western Australia in 1931, under Chief Protector of Aborigines, A. O. Neville. In the first spoken words of the film, Molly states in dialect: 'This is a true story ...' As the scene unfolds, the female kin group - Molly, Daisy, Gracie, their mothers and grandmother - converse in dialect, while tracking a goanna. This scene signals the importance of maternal relations in handing on hunting and other survival skills, and an appreciation for country. Observing the group from up on a ridge, Hungerford, the manager of Jigalong depot, identifies the girls for Constable Riggs, who is preparing to remove them. Sometime later, inside a shed, Riggs watches and waits for the children. While their mothers collect rations, the girls chat idly with a young white man who, like their father, works on the 
rabbit-proof fence. When they suddenly hear a car, the mothers flee, grabbing the children as they run. The sound of a camel roaring and drums beating heightens the emotional intensity. Trapping the women and girls between the fence and his car, Riggs jumps out and violently wrenches the girls away from their mothers. As he shoves them into the car, he waves a piece of paper, shouting: "It's the law Maude ... . Nothing you can do". She protests violently that they are her children, that Molly is going to marry soon, and they belong in their country. Screaming and wailing, the women beat on the windows and chase the car. As it speeds away, the two mothers lie crumpled in the dirt, while the girls' grandmother pounds her head with a rock. Noyce uses these images of grieving mothers and terrified children, struggling with an overpowering paternal authority, to powerful emotional effect. Close-ups invite audiences to identify with the mothers' grief and the children's fear. At the same time, however, the ending of this scene, in which the women perform their abject status by self-harming and lying in the road like corpses, stages an unpalatable and rarely expressed truth that pushes at the limits of the sentimental framing. This tragic scene acknowledges that the government's assimilation policy renders the mothers disposable, easily replaced by other preferred guardians. The "law" not only legitimates the theft of their children; it robs the women of their cultural and legal status as mothers.

While the overwhelming emotional pull of the removal scene is with the mothers and children, it is worth noting that there are two non-Indigenous witnesses in this scene: the depot manager Hungerford, and the fence worker. Hungerford, who knows the girls are about to be taken, remains distanced and impassive during their capture. By contrast, the young fence worker shifts uncomfortably at the margins of the scene, raising his hand to his mouth in an expression of alarm as he watches the girls being torn from their mothers. In his T-shirt and khakis, he appears powerless in the face of the commanding paternal authority of the uniformed Riggs. Through this sympathetic, yet ambiguous figure, the film fleetingly acknowledges, and invites the viewer to acknowledge, the passive complicity of ordinary Australians in Indigenous child removal. Yet, the rhetorical force of the bystander figure is lessened by the sentimental focus on the struggle between Riggs, the girls and their mothers. In contrast, the young man appears only for an instant. For the most part, the film distances viewers from reflecting critically on the compromised positions of the white characters and instead elicits identification with the purity of maternal grief and childhood innocence.

Rabbit Proof Fence ends with the unexpected revelation of repeated trauma, which heightens the intensity of maternal suffering. After weeks of walking and near-death experiences, the girls approach the outskirts of Jigalong at dusk. Constable Riggs hears commotion from the women's camp, which is preparing for the girls' arrival, and goes to investigate. In a scene that conveys the menace of the Australian bush and the 'otherness' of Indigeneity, Riggs is confronted by Molly's mother and grandmother, threatening him with spears. Spooked by the call of a bird, and the rage of the women, he runs off. As dawn breaks, Molly and Daisy are met by their mother and grandmother. In a scene of joyous reunion, 
laden with pathos, Molly runs into her grandmother's arms. As they embrace, she repeatedly sobs 'I lost one,' a reference to Gracie's recapture. Molly's grief at her 'loss' of Gracie prefigures her later grief at the loss of her own daughter. The film cuts to Neville in his office, acknowledging that he has no further resources to recapture the girls, but asking the depot officer to keep an eye on them for the future.

The next and penultimate scene, which continues the story after the triumphant return of Molly and Daisy to Jigalong, is electrifying. As the camera pans over the bush, viewers hear Molly speaking in dialect. The translation reads:

Then we went and hid in the desert. Got married. I had 2 baby girls. Then they took me and my kids back to that place, Moore River. And I walked all the way ... back to Jigalong again, carrying Annabelle... When she was 3, that Mr Neville took her away. I've never seen her again. Gracie is dead now. She never made it back to Jigalong.

This analeptic description of Molly's own experience as a mother is shocking enough, but what is not made explicit is that Molly had to leave four-year-old Doris behind when she carried Annabelle to Jigalong. Much of the debate about the film focuses on its sentimentality, which is anchored in maternal tropes, but critics have tended to overlook the film's acknowledgment of the limits of translating trauma across cultural difference. ${ }^{14}$ The devastating revelation of repeated trauma is mediated through an Indigenous voice, which is a tribute to Pilkington, who strived to respect Aboriginal knowledge and customs while translating them for non-Indigenous audiences. The linguistic dissonance of the Aboriginal voice - so unexpected in a commercial 'Hollywood' film — signifies the untranslatability of traumatic memory. Molly's voice powerfully conveys the extent to which the affective legacy of trauma cannot be shared, but rather isolates the women. What Holocaust survivor Charlotte Delbo calls the 'sensory memory' of trauma - in this case, perhaps Molly's bodily memory of carrying a toddler $1600 \mathrm{~km}$, while grieving for the child she has left behind - is registered, but not 'translated', through Molly's embodied voice.

In the final frames of the film, the real Molly and Daisy, now old women, stand on a hill in Jigalong. Molly says: 'Daisy and me, we're living here in our country. We're never going back to that place' which refers to Moore River, but could also refer to the 'place' of traumatic memory. ${ }^{15}$ Structurally, the documentary ending is similar to that of Schindler's List, in that both films introduce the real historical figures to reiterate the 'truth' of the narrative, and to bring the legacy of the past into the present. But the affect of the scenes is entirely different. In Schindler's List, the survivors, surrounded by their families, confirm their survival and procreation. In Rabbit-Proof Fence, the women stand alone, which reminds viewers of those who have not come home. The intense sense of maternal loss, conveyed through Molly's narrative of her stolen daughters and the loss of Gracie, is alleviated only through her connection with the land, which enables survival in the face of the government's relentless assault on Indigenous 
family bonds. Although the diegetic ending provides closure, with the girls successfully arriving home, the film concludes, through the extra-diegetic ending, without resolution or reconciliation. While Rabbit Proof Fence tells only one story, a rare story, it is often curiously taken as representative. Thus, its particular representation of the girls' longing for home and mother is made to stand for a cultural rather than a personal memory of the Stolen Generations, in which nostalgia for home and maternal loss are dominant tropes.

\section{Trauma Narrative from National to Transnational}

Use of the maternal trope is further evidenced in the international marketing campaign for the film, which involved the re-packaging of Pilkington's memoir as a tie-in with the film. A reading of the covers of Rabbit Proof Fence, from its first edition in 1996 to its most recent edition in 2005, reveals the prevalence of gendered imagery in mediating the shift from a local to a global market, and in constructing a cultural memory of Stolen Generations. These covers are an example of what Gerard Genette calls 'peritexts': those texts that wrap, mediate and give meaning to the main text. In contrast to the Australian vernacular aesthetic signified by the benign pastoral scene on the cover of the first Australian edition of Pilkington's memoir, the global marketing of RabbitProof Fence used iconography associated with a gendered visual aesthetic of trauma and distant suffering - drawn from the iconography of the Holocaust, and of refugees escaping from peril. The covers of the 2002 edition of the book, and the DVD, carry a film still of Molly carrying a wounded and emaciated Daisy home. Both girls are dressed in the tattered, shapeless dress of a refugee camp; behind them is a barbed-wire fence. The clouds are an ominous orange and brown, connoting smoke. In the context of the Bosnian and Serbian wars of the 1990s, and the Rwandan genocide, this visual framing of the Stolen Generations links it to international atrocities, and positions it for a global market hungry for stories of trauma and distant suffering.

If the marketing for North American and European audiences rhetorically and visually linked the Stolen Generations to the Holocaust and the global refugee crisis, in Japan the historical and political connotations of the film were downplayed in favour of a sentimental framing. A Japanese advertisement promoted the film as 'a universal story about the separation of mother and child'. The advertisement added an element of adventure: 'I just want to see my mum. There are $1500 \mathrm{~km}$ to my hometown, where my mum is waiting.' What makes the story 'universal', of course, is its celebration of the bond between mother and child. If the film's reception in Japan is indicative, Rabbit Proof Fence was not widely received as a story about the traumas of colonialism, and how the legacy of dispossession and colonialism continues to impact upon Aboriginal Australians in the present. ${ }^{16}$ In 2006, Pilkington produced a children's version of her mother's story, titled Home to Mother, which like the Japanese ad, mediates the story through the maternal bond. This commodification and the 
various iterations of the Rabbit Proof Fence narrative, and the iconic status of this particular version of Stolen Generations trauma, disavows the less culturally palatable effects of child removal and assimilation - the ambivalences and potentially irreparable estrangement of the mother-child relation. These are the taboos that Kofman engages with so bravely. So, too, has Doris Pilkington, although her narrative of the estrangement of mother-child bonds that occurred in her own family is less well known.

\section{Unsettling the Maternal Trope}

When she died in 2004, Molly said she had 'one regret' - that she did not see her daughter Annabelle again (Collins and Davis 144). In their reading of Rabbit Proof Fence, Felicity Collins and Theresa Davis regard Molly's statement as revealing what is 'unspeakable' or 'unrecoverable' in her story - that is, the traumatic loss of her daughter (145). There is, however, another dimension to Molly's story, not available to global or national audiences, that reveals a further layer of trauma that cannot be integrated into a sentimental framing. At a public screening of Rabbit Proof Fence in 2005, Pilkington told the audience that she had contacted her sister before their mother died, and told her of their mother's wish to see her. But her sister, for private reasons of her own, did not want to meet her mother or kin, and refused to travel to Jigalong. ${ }^{17}$ Her sister's children, who did not know they had Aboriginal family, wanted to meet their relatives. Their mother sent them, with a tin of biscuits, to see their grandmother in Jigalong, who allegedly responded: 'your mother should have brought these herself'. In the ending of the film, Annabelle is figured as a 'lost' child, but in Pilkington's oral commentary she emerges as a 'resistant' adult daughter who refuses to return 'home'. In an unexpected echo of Kofman's memoir, we discover that Molly is not only a bereaved mother but a rejected mother. This anecdotal fragment suggests complexities of experience, emotion and memory that go beyond what can be conveyed through images of suffering mothers and vulnerable children. Pilkington's poignant revelation shocked the audience, confronting us with a concrete case in which the intended aim of the assimilation policy - to pervert and estrange intimate Indigenous family bonds by severing relations between children and their Aboriginal kin - was realized. Her oral commentary reveals the traumatic, intergenerational legacy of child removal: for her mother, unrequited love and life-long suffering; for the daughter and her children, loss of culture and family. This knowledge intensifies the sense of loss associated with the nonredemptive ending of Rabbit-Proof Fence, leaving us to ponder the enormous social and personal costs of Indigenous child removal.

In a context in which healing is largely conceptualised as being reunited with lost family, stories about estranged family relations can be impossible to tell. In the current political climate, in which Stolen Generations narratives 'focus on the traumatic effects of forced removals', positive memoirs of removal and assimilation have been greeted with scepticism and charges of denial (Whitlock 
31). In this context, the 'lost' daughter's story of why she chose not to return to 'home' and mother may not be welcome. ${ }^{18}$ Moreover, the polarised discursive context - in which child removal is interpreted through politicised dichotomies of 'loss' or 'benefit', 'theft' or 'rescue' - makes it difficult to tell stories in which these categories are blurred. The story of the Stolen Generations, as mediated through the maternal trope, is a trauma narrative with which audiences can readily identify. ${ }^{19}$ For a non-sentimental rendering of maternal-child relations, it is useful to turn to Kofman's text. How do other dimensions of mother-child relations emerge within Holocaust testimony? What tropes and figures does Kofman use in narrating a story of mother-daughter relations estranged by traumatic events, of the impossibility of returning 'home', and of the difficulties of distinguishing rescue from theft, and protection from abuse?

\section{'The Strange and Estranging Legacy of Trauma': Rue Ordener, Rue Labat}

Kofman's memoir is grounded in her personal, embodied memory of events, but also informed by her practice as a philosopher who has published on the unspeakability of the Holocaust. ${ }^{20}$ As a scholar of Freud's work and an analysand over many years, she writes from within a European tradition of psychoanalysis. She begins Rue Ordener/Rue Labat by acknowledging her delay in writing about 'that' - a term which confers the 'unspeakability' of trauma on the memory of her father's deportation and death, and the irrevocable end of family life as she had known it. Yet, she goes on to write about the horror and loss, the betrayal and shame, which cannot be spoken. The text does not linguistically 'act out' traumatic memory through flashbacks and memory fragments; nor is the reader presented with 'bits and pieces of memory overwhelmed by events' (Felman and Laub). Rather, Kofman's style, like that of Primo Levi and Ruth Kluger, is striking for its precision and almost clinical clarity. This clarity suggests a traumatic memory that has been 'radically rethought and fundamentally worked over by the text' (Felman and Laub xiv-xv). The title, which refers to the Parisian streets on which her family and Meme lived, signifies a splitting of the site of 'home' and identity. The memoir succeeds in transmitting the 'strange and estranging legacy of trauma' by revealing how the deportation of her father, the splitting of the family, and her mother's powerlessness in hiding, resulted in a traumatic breach in mother-child relations (Brodzki 129).

The core of Kofman's memoir details the domestic drama played out in hiding. She conveys the intensity of the mother-child bond through repeated scenes in which Sarah acts out her terror of what, as a child, she perceived to be 'the real danger: separation from my mother' (33). She depicts herself, even before her father's arrest, as a highly-strung and often ill child, who suffered from a terror of being abandoned, and who developed strong attachments to mother figures. When her mother hides the children in the country, she refuses to eat pork, and frequently vomits, thereby endangering herself and her siblings. ${ }^{21}$ After the roundups intensify, her mother hides her in Paris, with a family, in a hospital, in a 
boarding house, but she always refused to eat pork, and sobs violently when her mother leaves her. Finally, after nearly leaving her at a monastery which was later raided, her mother decides to keep Sarah with her, until, in February, 1943 'it' happened: they are warned they are 'on the list' for that night. They seek refuge with Meme, who had once been their neighbour (31). The next day Sarah returns with her mother to their flat to find that it has been vandalised by the Gestapo. If, in later life, Kofman feels any nostalgia for her childhood home, it is not conveyed. Rather, her admission - ' [n]ever again, except in dreams, have I ever gone back there'-suggests the utter impossibility of a return home, and the profound rupture the Holocaust brought about in Jewish family life (33).

With analytical insight, Kofman describes how a situation of rescue became, for her mother, one of psychological and emotional abuse. Once Sarah and her mother move into Meme's apartment, Sarah's transformation into a 'Christian girl' is set in train. Meme calls her by the Christian name 'Suzanne'. Rather than use food simply to nurture Sarah, Meme uses it as a weapon in her battle against the 'other' mother. Insisting that 'the food of my childhood was unhealthy; I was pale, "lymphatic," I must change my diet' Meme took over caring for Sarah (40). Meme makes her new clothes, supplies her with books, lavishes her with affection, and takes her for walks during which Sarah passes as her daughter. Meme is associated with sensual and illicit bodily pleasures: she kisses Sarah, walks around her apartment bare-chested, and has her lover to spend the night once a week. The young Sarah describes her own reaction to Meme as a kind of seduction: she blushes when she watches Meme undress behind a screen, and welcomes the affection Meme, unlike her own mother, lavishes on her. Kofman recalls how Meme's 'care' led to amnesia:

I had, it seemed, buried the entire past: I started loving rare steak cooked in butter and parsley. I didn't think any more at all about my father, and I couldn't pronounce a single word of Yiddish despite the fact that I could still understand the language of my childhood perfectly (57).

Kofman does not represent herself as resistant or innocent, but rather as complicit. She recalls how easy she made it for Meme to win her over, and the pain she half-knowingly inflicted on her mother. For instance, she recalls a Mother's Day when, after agonising, she decided to give the more beautiful of the two cards she has bought to Meme. Her wording - 'my choice has undeniably been made' (45) - positions her childhood self as aware of her betrayal. Her intense bond with Meme culminates in an episode in which the two go to the country one Sunday to visit Meme's family, and miss the last metro home. They stay in a hotel, and Sarah, who shares a bed with Meme, is 'relieved' not to have to walk the formidable distance to Rue Labat. But her mother looms like a disturbing presence that keeps Sarah from guiltlessly enjoying her pleasure with Meme, as she worried '.. about separation from my mother' whom she knows will be frantic (55). Kofman recalls that by the time Paris is liberated, and they come out of hiding, '[m]y mother felt nothing any more but hate and contempt 
for the woman who'd saved our lives' (58). The feelings of anxiety and dread that Sarah had previously experienced at being separated from her mother are transferred to Meme: 'It tore me in two. Overnight I had to take leave of the woman I now loved more than my own mother' (58). From her child's point of view, she is not liberated but rather subjected to another 'traumatic separation', and consigned to a miserable life in a dirty, crowded hotel with her mother and siblings.

Whereas Kofman remembers her father only lovingly, she recalls incriminating details about her mother (as if she has taken on the role of 'prosecuting' her mother). After they leave Meme's, her mother allows her one-hour visits to ease the transition: "If I stayed away a second too long, she would beat me with a strap ... I was soon covered with bruises and began to detest my mother ... strangely enough, she had thought to bring that strap with her the day we escaped ...' (59). Her mother sues Meme for having 'tried to "take advantage" of me and of having mistreated [her] ...' (59). In a disturbing inversion of Foigel's testimony, Kofman confesses that she testified against her 'cruel' mother, showing the court her bruises. The court decides to leave Sarah in Meme's care. The guilt she feels manifests itself, as usual, in bodily symptoms (60). When Meme calls her lover Paul to tell him that she won the suit, Sarah's stomach 'was in a knot. I peered around me in the street as if I had just committed a crime - as if once again I were "wanted"' (61). In her recollection of this incident, her mother has become a perpetrator who, like the Nazis, hunts the child down in an effort to steal her from the 'mother' she now loves more than her own. The young Sarah plays the role of the hunted, frequently running away to Meme, flouting her mother's rules and wishes. Yet, she also recalls her ambivalent relief when her mother, accompanied by two burly men, 'steals' her back from Meme. In conveying this episode, in which no one behaves selflessly, Kofman's memoir reveals how the assimilation of the child can lead to the perversion of motherchild relations. Her 'troubling confession' challenges our notions of maternal self-sacrifice and childhood innocence (Brooks). It acknowledges how traumatic experience produces estrangement and alienation in the intimate relations that are, as we have seen, conventionally represented in the most sentimental ways in popular versions of Stolen Generations story.

Kofman mediates her memory of childhood trauma through two cultural narratives of mother-child relations, thereby suggesting this maternal dimension of her memoir might be placed in a broader comparative context. Both these narratives reflect on the mutability of subject positions in contexts of unequal power in intimate relations. The first is a Leonardo da Vinci painting, Madonna and Child with St. Anne, in which two women look lovingly at the infant, while an older woman is in the background. When da Vinci's father re-married, his mother was 'replaced' in his affections by his loving step-mother. Freud comments that: "The artist seems to have used the blissful smile of St. Anne to disavow and to cloak the envy which the unfortunate woman felt when she was forced to give up her son to her better-born rival, as she had once given up his father as well" (64). Kofman's memoir of her survival in hiding can also be read as a theft masked 
through affection and care. Meme uses the pretext of offering 'protection' to disavow her anti-Semitism; she masks her cruel behaviour to Sarah's mother's by offering to 'ease' her burden.

The second example is Kofman's discussion of a scene from Alfred Hitchcock's film, The Lady Vanishes, in which the good little old lady, Mrs. Froy, is replaced by another woman pretending to be her. Kofman says her 'agony is excruciating' when the young woman who had been talking to Mrs Froy, and who has been knocked unconscious, is half-convinced by a pseudo-doctor that she only imagined Mrs. Froy was there, and the other woman had always been there. Kofman interprets this scene as a story about good and bad mothers and the difficulty of telling the two apart: 'The bad breast in place of the good, the one utterly separate from the other, the one changing into the other' (66). Whereas in the Da Vinci painting the child is unaware of events, in this scene the young woman, here representing Kofman's own position, is suspicious that she has been duped - that the good Mrs. Froy has been replaced by an evil woman. Using this scene to mediate her memory of her 'improper' childhood feelings towards her 'two mothers', Kofman suggests the impossibility of making easy or clear distinctions between 'good' and 'bad' mothers, and between 'beneficiaries' and 'victims'. Her mother is not only the suffering mother, but also the cruel mother. Meme is not simply a saviour; she is also an opportunist and beneficiary. Sarah is not simply the innocent child, but the accusing and complicit child; not simply the 'stolen' child but the child who gains pleasure from a new intimate relationship. Rather than provide closure, Kofman ends her memoir with the unapologetic confession that she did not attend Meme's funeral-another acknowledgment of the estranging legacy of trauma. Anti-heroic and unsentimental, her memoir makes uncomfortable reading as there is no apparent reconciliation, no atonement, no forgiveness, only bitterness, regret and guilt.

The debate on the 'limits of representation' often turns on what can be visually represented in Holocaust cinema. Kofman's memoir draws attention to other unspoken limits of representation - particularly regarding mother-child relations. Unlike Rabbit-Proof Fence, which invites identification with the mothers and children, Kofman's memoir distances the readers, and calls for critical reflection rather than empathy and identification. With whom would the reader wish to identify in this memoir about the seductions of assimilation, cruel mothers, a defiant daughter, and the difficulties of reparation? Like Ruth Kluger's memoir, Still Alive: A Holocaust Girlhood Remembered, Kofman's memoir contributes to a literary tradition of intimate trauma memoir in which mothers and daughters do not behave heroically or selflessly. These unforgiving memoirs, in which memory surfaces through bile, confront the reader with psychological legacies and moral shortcomings that we deal with in denial. These complex and painful realities have not been integrated into the cultural memory of the Stolen Generations, but as we have seen, circulate in the margins - such as in Pilkington's oral commentary. 


\section{Conclusion: Legacies of Post/Colonial Trauma in the $21^{\text {st }}$ Century}

Rabbit Proof Fence represents Indigenous child removal as a past event. As recent events suggest, however, the traumatic legacy of child removal, dispossession and colonisation continues to be acted out in Indigenous communities. Ten years after Bringing Them Home, the discourses and subject positions the assimilation policy produced - particularly that of the vulnerable child and its counterpart, the state as stern but benevolent father - have achieved new potency. In June 2007, the Northern Territory government issued a report, Little Children Are Sacred, which documented shocking cases of child sexual abuse in remote Indigenous communities. As the report's title indicates, the figure of the vulnerable child is a recurrent and emotive signifier in the discourse of child protection. In response to the report, the federal government, led by then Prime Minister John Howard, declared a state of 'national emergency'. Howard and his Indigenous Affairs Minister Mal Brough devised a controversial plan of action that became known as the 'Northern Territory Intervention'. Taking what could be described as a 'muscular humanitarian' approach, the government spent millions, bringing in the army, police, bureaucrats and teams of medical personnel to conduct child health checks and curb lawlessness. ${ }^{22}$

From its inception, the intervention divided the Indigenous community and its supporters. ${ }^{23}$ While Social Justice Commissioner Tom Calma saw the intervention as an assault on Indigenous rights, Aboriginal leader Noel Pearson used the trope of the 'terrified child huddled in the corner' to garner support for the intervention. ${ }^{24}$ Much has changed since the intervention began: Howard lost power in November 2007, and Kevin Rudd, who became prime minister, offered a long-awaited national apology to members of the Stolen Generations in February 2008. The extensive media, academic and policy commentary and analysis of the intervention has revealed that the scope and depth of problems in remote Indigenous communities[0] - alcohol and drug abuse, lawlessness, suicide, poor health, education and child neglect, lack of job opportunities - go far beyond child sexual abuse, and defy easy solutions. The Rudd government, which supported the intervention, is currently undertaking a review to determine its future. Although I cannot discuss the discourses surrounding the intervention in depth, I will tie together the threads of my argument by considering some of the effects of the trope of the vulnerable child, and the legacy of post/colonial trauma in the $21^{\text {st }}$ century.

One of the first newspaper articles to report the intervention used a striking image - a paternal inversion of the maternal trope - to mediate the story (Coorey et al). ${ }^{25}$ This image is significant because it anticipated the main fault line in the debate about the intervention: paternalistic opportunism or legitimate 'practical' solution to a dire situation? Covering the top half of a page in the Sydney Morning Herald, the image consisted of a windblown Aboriginal flag, frayed at the edges. Inside the yellow circle of the flag is a cropped photograph of then Prime Minister Howard, wearing an Akubra, holding an Aboriginal female toddler. ${ }^{26}$ Howard, representative of the authority and 
power of the state, is positioned as the 'father' of the nation and protector of Aboriginal children. Mediated by the Aboriginal flag, and cropped to focus on the father/child dyad, the photograph invites readers to link the intervention with the Stolen Generations, thereby framing the government's strategy as paternalistic and denying Aboriginal rights. On another reading, the frayed flag suggests that Indigenous communities are in need of urgent help, with the state positioned as legitimate protector of the children. What is telling, for the argument I have been developing, is the replacement of the Indigenous mother (as featured on the cover of Bringing Them Home) by the white 'father', once again positioning her as dispensable. In discursive terms, the Indigenous mother is locked into an oppositional binary with the Indigenous male, who has been positioned, in the intervention discourse, as a sexual predator. ${ }^{27}$ Thus, Indigenous women are positioned as either 'protecting' the men (rather than the children), and thus opposed to the intervention, or in need of protection from Indigenous male violence, and thus as supporting the intervention. In either case, the threat to indigenous children has been figured as coming primarily from within Indigenous communities - a major shift in the discourse from the National Inquiry, which documented extensive child abuse by non-Indigenous caretakers. ${ }^{28}$

As the above image indicates, the discourse of the intervention has focused almost exclusively on the needs of the 'vulnerable child', considering other members of the community primarily in relation to the child. For instance, in the newspaper article accompanying the image, Howard's rhetorical use of 'little children' lends moral support to the intervention: "I am distressed ... Little children. It is a disgrace that a section of the Australian population, that little children should be the subject of serious sexual abuse" (Coorey et al). As the Northern Territory report makes clear, however, it is not only little children who are suffering and at risk; adults are suffering too, and desperately need help: 'The inquiry found a deeply entrenched and self-sustaining cycle of abuse and violence which had become an inheritance, passing from one generation to the next' (Coorey et al). Illustrating the repetitive nature of trauma, the article quotes testimony by a jailed rapist: "When I was six my old man shot my mum ... bang in the head. They had been blueing all night. He made me clean her brains off the floor. When I raped that girl I felt like all my pain was going into her, when she screamed, that was me screaming" (Coorey et al). This horrific testimony documents an intergenerational cycle of trauma, which is too rarely acknowledged - in part because it is seen as providing excuses for perpetrators. The belief that acknowledging causes of violence, including historical causes, is to excuse violence operates as a firm limit in the intervention discourse, which blocks recognition of the repetitive cycle of trauma.

Like Sarah Kofman in her memoir, Indigenous professor Judy Atkinson, who works on trauma and healing in Indigenous communities, recognises the difficulty of making clear-cut distinctions between 'victim', 'perpetrator', 'collaborator' and 'beneficiary'. With an awareness of the rhetorical power of the figure of the child, Atkinson positions the 'rapist' as someone who was once a vulnerable child. Identifying a major problem that limits long-term healing, she asks: "How 
many skilled people do we have in Australia who can work with that child, to intervene to stop that child raping when he grows up? There aren't many" (Coorey et al, my italics). Whereas Howard focused on the 'little child' in isolation from other members of the community, Atkinson's point is that 'perpetrators' must be treated, not simply excluded or penalised, if the cycle of violence is to be reduced. Speaking of the rapist, she comments: "When a child is that deeply traumatised, he becomes rewired, he can't study ... We need to put healing into the curriculum" (Coorey et al 25). Mick Dodson also points to the need for treatment: "The prohibition of alcohol - that doesn't work because we have to deal with ... the addiction. We've got to give these people support, counselling" (Coorey et al 25). ${ }^{29}$ These Indigenous leaders are not opposed to the intervention. They recognise, however, that traumatic events have a tendency to repeat, and produce legacies that cannot be resolved only through practical solutions such as monitoring welfare payments and school attendance, although such policies are part of a solution. Post-trauma counselling is also part of a practical solution, but it requires massive resources which are scarce. Pilkington's oral commentary and Kofman's memoir are important in the context of the national emergency, in that they make us aware of the estranging and repetitive legacy of trauma. If more lives are not to be wasted, implicitly regarded as disposable, a response must recognise the intergenerational repetition of trauma, and provide resources for treatment and healing to all members of the community.

\section{Notes}

[1] For discussions of Kofman's memoir in relation to her philosophy, see Deutscher and Oliver; Oliver; and Chanter.

[2] Suicides often prompt a re-reading of an author's earlier works in light of this final act; on Kofman's suicide, see (Robson 616-617), (Deutsche and Oliver 8) and (Dobie vii-xiv).

[3] The late psychoanalyst Dori Laub has argued that, to stop acting out a traumatic event, the survivor needs to integrate the memory fragments into a narrative, which will aid survival. He maintains that the therapeutic process of the 're-externalization of the event can occur and take effect only when one can articulate and transmit the story, literally transfer it to another outside oneself and then take it back again, inside' (Felman and Laub 69). He proposes that Holocaust survivors 'needed to tell their story in order to survive' (Felman and Laub 78).

[4] My account is indebted to Golasan.

[5] The claim that 'stolen generations' testimonies penetrated the heart of nonIndigenous Australia in the way other Indigenous issues had not is frequently repeated. At the tenth anniversary of Bringing Them Home at Parliament House, Canberra, on May 27, 2007, an Indigenous speaker commented that unlike other Aboriginal issues, the 'stolen generations' had generated intense empathy among non-Indigenous Australians 'because everyone has a mother ... and everyone has been a child.' Author's personal observation.

[6] I have explored some of the diverse ways in which non-Indigenous Australians have responded to stolen generations testimony in Kennedy 2004.

[7] See the essays in Curthoys and Docker, and Moses. 
[8] I may be regarded as doing violence to Kofman's text by reading it in a context so foreign to her own interests, but I believe this is one of the possibilities generated by a transnational Holocaust memory discourse - that is enables comparisons that may not seem 'appropriate' but that may produce new insights.

[9] Since I am primarily concerned with reading Kofman's memoir in an Australian context, where the English translation is more readily available than the French original, I have quoted from the English.

[10] Barbara Creed reads Jedda retrospectively as a 'stolen child' narrative, which presents for viewers today the uncomfortable issue of whether the white 'adopting' mother had any right to remove baby Jedda from her people and raise her as a 'white' child.

[11] For a powerful analysis of the position of the beneficiary in the South African Truth and Reconciliation Commission, see Schaffer and Smith.

[12] Pilkington (2002) has also published a memoir of her childhood and early adulthood, her unlearning of internalised racism, and her journey to Jigalong to find her family.

[13] As D'aeth observers:

Both films are based on non-fictional accounts ... of traumatic events that were founded on survivor testimony ... they are both survival stories that take place against a backdrop of non-survival ... escape stories that confound a more general condition of imprisonment. Each film also seems conditioned by the expectation that they are bringing their respective traumatic events to "the world" and present themselves implicitly as representative of a multitude of similar stories.

[14] For a range of views on the film's sentimentality, see Birch; Potter and Schaffer; and D'aeth. Collins and Davis argue that the ending of the film positions spectators as witnesses to Indigenous trauma.

[15] This scene recalls a scene in Claude Lanzmann's film, Shoah, in which one of the witnesses, Mordecai Polchebank, when asked what he feels about the horrors he witnessed in the Holocaust, responds: "I don't go back there".

[16] In marketing the film exclusively through the maternal trope, an opportunity was missed to draw attention to the struggle of Japan's indigenous peoples, the Ainu, who like Australian Aborigines have suffered from oppression, dispossession and child removal.

[17] Screening and discussion of Rabbit-Proof Fence with Doris Pilkington, National Library of Australia, 2005. Author's personal observation.

[18] Jay Arthur, a curator the National Museum of Australia, has discussed with me the difficulties of telling complex stories of removal, which might be seen to challenge the dominant narrative of traumatic separation (Kennedy 2008). See also Schaffer; Hosking.

[19] LaCapra argues that an empathic response to victims should not foreclose or become a substitute for 'attempts to work through the past and its losses, both in victims ... and in secondary witnesses' (47). See also his discussion on pp. 212-213.

[20] Kofman first wrote about the Holocaust and her father's deportation and death in Smothered Words, published in French in 1987. After this text, as Dobie notes, Judaism, anti-Semitism, the Shoah, and autobiography emerged as 'predominant concerns' in her work. Dobie describes Kofman's anti-sentimental approach: “by presenting the events [of her father's deportation] as a set of statistics, she banished the potential for pathos and avoids any attempt to describe or explain. She also underscores the fact that what she is describing is an historical as well as a personal trauma" (xi-xii).

[21] Robson offers a compelling analysis of the figure of the vomiting body in Kofman's memoir. 
[22] On muscular humanitarism, see Orford. The health checks were originally intended as 'forensic exams' to determine the extent of child sex abuse. In response to an outcry, including by doctors, the health checks were made voluntary, and did not seek evidence of sexual abuse. See Lateline interview with Mal Brough, aired on 20/ 6/2008, available at: http://www.abc.net.au/lateline/content/2007/s2281522. htm

[23] For some of the extensive $A B C$ coverage of the Northern Territory Intervention, see 'Lateline' and 'Breakfast' archives on http://www.abc.net.au , and see Four Corners, 'Tracking the Intervention', broadcast on 5/11/2007, available at http: //www.abc.net.au/4corners/content/2007/s2079819.htm For analysis of and critical responses to the National Emergency, see Altman and Hinkson, and Langton.

[24] Pearson used the emotive figure of 'the child huddled in the corner' in an interview with Fran Kelley on Radio National Breakfast, 20 June 2007, at http://www.abc. net.au/rn/breakfast/stories/2007/1956365.htm - 6k - [ html ] - 20 Jun 2007. Tom Calma responded on the same show the following day: www.abc.net.au/rn/ breakfast/stories/2007/1956365.htm - 6k - [ html ] - 21 Jun 2007. The figure of the vulnerable child has been taken up by conservative commentators such as The Australian columnist Janet Albrechtson to defend the government intervention plan against charges of 'paternalism' and 'racial discrimination'.

[25] I would like to thank Sue Andrews for drawing this article to my attention.

[26] Three months later, in an article discussing Howard's shock announcement that, if re-elected, he would hold a referendum to recognise Indigenous Australians in a preamble to the Constitution, The Australian printed the photograph from which the figure of Howard holding the child was cropped. In the photograph, taken in 2005, Howard is visiting a Northern Territory community, and is surrounded by children of all ages.

[27] At the October 13, 2007 opening of the 'Culture Warriors' Indigenous art exhibit at the National Gallery of Australia, artist Vernon Ah Kee wore a black T-shirt which read: "I do not bash women": In his talk, he objected to the government's discourse on Northern Territory communities, which positioned all Indigenous men as rapists, paedophiles, alcoholics and wife-beaters. Author's personal observation.

[28] In the article accompanying the image, the journalist comments that Judy Atkinson "knows the self-perpetuating nature of the problem [of sexual abuse]. She herself, a Jiman woman from Central Queensland, was sexually abused as a child by a [white?] church official". This important detail reminds readers that perpetrators use positions of authority to gain access to children, and come from outside as well as within Indigenous communities.

[29] In an essay on Indigenous male violence, Greer (2008) argues that it is important to treat the 'underlying pathology'. Also see her interview with Fran Kelly on Radio National Breakfast, August 14, 2008: http://www.abc.net.au/rn/breakfast/stories/ 2008/2334875.htm

\section{References}

Altman, Jon and Melinda Hinkson, eds. Coercive Reconciliation: Stabilise, Normalise, Exit Aboriginal Australia. Melbourne: Arena Publications, 2007.

Anderson, Patricia and Rex Wild, QC. Little Children Are Sacred: Report of the Northern Territory Board of Inquiry into the Protection of Aboriginal Children from Sexual Abuse (2007). 
Bennett, Jill and Rosanne Kennedy. 'Introduction.' World Memory: Personal Trajectories in Global Time. Ed. Jill Bennett and Rosanne Kennedy. London: Palgrave-Macmillan, 2003.

Birch, Tony. 'This is a True Story: Rabbi-Proof Fence, 'Mr Devil' and the Desire to Forget'. Cultural Studies Review. 8.1 (2002): 117-129.

Brodzki, Bella. 'Trauma and Transmission.' Teaching the Representation of the Holocaust. Ed. Marianne Hirsch and Irene Kacandes. New York, N.Y: Modern Language Association of America, 2004.

Brooks, Peter. Troubling Confessions: Speaking Guilt in Law and Literature. Chicago: University of Chicago Press, 2000.

Collins, Felicity, and Theresa, Davis. Australian Cinema After Mabo. Cambridge, U.K.; New York: Cambridge University Press, 2004.

Chanter, Tina. 'Eating Words: Antigone as Kofman's Proper Name'. Enigmas: Essays on Sarah Kofman. Ed. Penelope Deutscher and Kelly Oliver. New York: Cornell University Press, 1999.

Coorey, Phillip, Peter Hartcher and Stephanie Peatling. 'Just Imagine if it was Marrickville: Why the Prime Minister Took Control'. The Sydney Morning Herald: Weekend Edition, June 23-25, 2007: 25.

Creed, Barbara. 'Breeding Out the Black: Jedda and the Stolen Generations in Australia'. Body Trade: Captivity, Cannibalism and Colonialism in the Pacific. Ed. Barbara Creed and Jeanette Hoorn. New York: Routledge, 2001.

Curthoys, Ann and John Docker, eds. Special section on 'Genocide'. Aboriginal History. 26 (2001).

D'aeth, Tony Hughes. 'Which Rabbit-Proof Fence? Empathy, Assimilation, Hollywood.' Australian Humanities Review (2002). //www.lib.latrobe.edu.au/AHR/archive/IssueSeptember-2002/hughesdaeth.htm $>$.

Deutscher, Penelope and Kelly Oliver. 'Introduction: Sarah Kofman's Skirts'. Enigmas: Essays on Sarah Kofman. Ed. Penelope Deutscher and Kelly Oliver. New York: Cornell University Press, 1999.

Dobie, Madeleine. 'Translator's Introduction'. Smothered Words. Sarah Kofman. Trans. by Madeleine Dobie. Evanston: Northwestern University Press, 1998.

Felman, Shoshana, and Dori Laub. Testimony: Crises of Witnessing in Literature, Psychoanalysis, and History. New York and London: Routledge, 1992.

Genette, Gérard. Paratexts: Thresholds of Interpretation. Trans. Jane E. Lewis. Cambridge; New York, NY, USA: Cambridge University Press, 1997.

Golasan, Richard J. 'The Legacy of World War II in France: Mapping the Discourses of Memory.' The Politics of Memory in Postwar Europe. Ed. Richard Ned Lebow, Wulf Kansteiner, and Claudio Fogu. Durham and London: Duke University Press, 2006.

Greer, Germaine. On Rage. Melbourne: Melbourne University Press, 2008.

Hirsch, Marianne. 'Nazi Photographs in Post-Holocaust Art: Gender as an Idiom of Memorialization.' Phototextualities: Intersections of Photography and Narrative. Ed. Alex Hughes and Andrea Noble. 2003.

Hosking, Sue. Homeless at Home, Stolen and Saved: Three Colebrook Autobiographies. Westerly. 46 (2001): 65-73.

Kahane, Claire. 'Dark Mirrors: A Feminist Reflection on Holocaust Narrative and the Maternal Metaphor.' Feminist Consequences: Theory for the New Century. Ed. Elisabeth Bronfen and Misha Kavka. New York: Columbia University Press, 2001.

Kennedy, Rosanne. 'The Affective Work of Stolen Generations Testimony: From the Archives to the Classroom'. Biography. 27.1 (2004): 48-77.

. 'Subversive Witnessing: Mediating Indigenous Testimony in Cultural and Legal Institutions in Australia.' Women's Studies Quarterly. 36.1 \& 2 (2008): 58-75.

Kluger, Ruth. Still Alive: a Holocaust Girlhood Remembered. New York: Feminist Press at the City University of New York, 2001. 
Kofman, Sarah. Rue Ordener, Rue Labat. Paris: Editions Galilee, 1994.

- Rue Ordener, Rue Labat. Trans. Ann Smock. Lincoln and London: University of Nebraska Press, 1996.

. Smothered Words. Trans. Madeleine Dobie. Evanston: Northwestern University Press, 1998.

LaCapra, Dominick. Writing History, Writing Trauma. Baltimore: The Johns Hopkins University Press, 2001.

Levi, Neil. “"No Sensible Comparison”? The Place of the Holocaust in Australia's History Wars'. History \& Memory 19.1 (2007): 124-156.

Langton, Marcia. 'Trapped in the Aboriginal Reality Show'. Griffith Review. 19 (2008).

Link-Up NSW Aboriginal Corporation and Tikka Jan Wilson. In the Best Interest of the Child? Canberra, A.C.T.: Aboriginal History, 1997.

Moses, A. Dirk. 'The Holocaust and Genocide.' The Historiography of the Holocaust. London: Palgrave Macmillan, 2004.

Noyce, Philip, Dir. Rabbit-Proof Fence. Australia, 2002.

Oliver, Kelly. 'Sarah Kofman's Queasy Stomach and the Riddle of the Paternal Law'. Enigmas: Essays on Sarah Kofman. Eds. Penelope Deutscher and Kelly Oliver. New York: Cornell University Press, 1999.

Orford, Anne. 'Muscular Humanitarianism: Reading the Narratives of the New Interventionism'. EJIL. 10.4 (1999): 679-711.

Pilkington Garimara, Doris. Follow the Rabbit-Proof Fence. St. Lucia, Queensland: University of Queensland Press, 1996.

Pilkington Garimara, Doris. Under the Wintamarra Tree. St. Lucia, Queensland: University of Queensland Press, 2002.

Pine, Lisa. 'Gender and the Family.' The Historiography of the Holocaust. London: Palgrave Macmillan, 2004.

Potter, Emily and Kay Schaffer. 'Rabbit-Proof Fence, Relational Ecologies and the Commodification of Indigenous Experience.' Australian Humanities Review. 31-32 (2004). http: / /www.lib.latrobe.edu.au/AHR/archive/Issue-April-2004/schaffer.html.

Robson, Kathryn. 'Bodily Detours: Sarah Kofman's Narratives of Childhood Trauma.' Modern Language Review. 99.3 (2004): 608-621.

Schaffer, Kay. 'Narrative Lives and Human Rights; Stolen Generation Narratives and the Ethics of Recognition.' Journal of the Association for the Study of Australian Literature. 3 (2004): 5-36.

Schaffer, Kay and Sidonie Smith. 'Human Rights, Storytelling, and the Position of the Beneficiary: Antjie Krog's Country of My Skull.' PMLA. 121.5 (2006): 1577-1584.

Shanahan, Dennis. 'Howard's Open Door'. Weekend Australian, October 13-14, 2007: 19-20.

Suleiman, Susan Rubin. 'The 1.5 Generation: Thinking About Child Survivors and the Holocaust.' American Imago. 59.3 (2002): 277-295.

Wieviorka, Annette. The Era of the Witness. Ithaca, NY: Cornell Univ. Press, 2006.

Whitlock, Gillian. 'Active remembrance: testimony, memoir and the work of reconciliation.' Rethinking Settler Colonialism: History and Memory in Australia, Canada, Aotearoa New Zealand and South Africa. Ed. Annie E. Coombes. Manchester and New York: Manchester University Press, 2006.

Wilson, Sir Ronald. Ed. Bringing Them Home: Report of the National Inquiry into the Separation of Aboriginal and Torres Strait Islander Children from Their Families. Sydney: Human Rights and Equal Opportunity Commission, 1997.

For comments on previous drafts of this article, I would like to thank Kate Douglas, Gillian Whitlock, Sue Andrews, Jeanette Hoorn and Rosemary Jolly. For 
inviting me to present this work and generously engaging with it, I would like to thank Mark Phillips, Ruth Phillips, Barbara Gabriel, and their graduate students in Cultural Mediations at Carleton University; the Centre for Research and Teaching on Women at McGill; and the audience at the 'Testimony and Witness' conference at the Australian National University. 